\title{
Factors Affecting Corruption in Indonesia: Study on Local Government in Indonesia
}

\section{Aris Eddy Sarwono ${ }^{1,2 *}$, Rahmawati Rahmawati ${ }^{3}$, Y. Anni Aryani ${ }^{4}$, Agung Nur Probohudono5}

\author{
${ }^{1}$ Universitas Slamet Riyadi, Faculty of Economics, Surakarta, Indonesia \\ ${ }^{2}$ Universitas Sebelas Maret, Department of Accounting, Surakarta, Indonesia \\ 3 Universitas Sebelas Maret, Department of Accounting, Surakarta, Indonesia \\ ${ }^{4}$ Universitas Sebelas Maret, Department of Accounting, Surakarta, Indonesia \\ ${ }^{5}$ Universitas Sebelas Maret, Department of Accounting, Surakarta, Indonesia \\ *Correspondence to: Aris Eddy Sarwono, Universitas Slamet Riyadi, Faculty of \\ Economics, Jl. Sumpah Pemuda No. 18, Kadipiro, Banjarsari, Surakarta, Jawa Tengah \\ 57136, Indonesia. \\ E-mail: aris_sarnur@yahoo.co.id
}

\begin{abstract}
This study aims to examine the factors that affecting corruption in Indonesia local governments. The sample used in this study consist of 225 Indonesian local governments. This study uses secondary data obtained from the Financial Audit Board (BPK) and Provincial Government's Financial Report (LKPD) from 2010-2014 period along with composition data that's obtained from the Regional House of Representatives (DPRD) in Indonesia. Data analysis were performed using regression analysis method. The results of the analysis show that corporate governance proxied with the composition of DPRDs that do not coalesce with the government, compared with the total DPRD has a significant effect on the corruption of local governments in Indonesia. The results of the analysis also show that the Regional Financial Information System (SIKD) has no effect on the corruption of local government. The control variables used in this study include the government's internal control system (weaknesses of accounting and reporting controls, weaknesses of controlling the execution of the budget and the weakness of the internal control structure) and the characteristics of local government (size of local government, asset, and balanced funds). The implication of this research is that governance in local government in Indonesia must be realized to prevent corruption, therefore the DPRD oversight function needs to be optimized.
\end{abstract}

Keywords: corruption, BPK, LKPD, SIKD, DPRD.

Article info: Received 27 March 2018; revised 26 April 2018; accepted 2 July 2018

Recommended citation: Sarwono, A. E., Rahmawati, R., Aryani, Y. A., \& Probohudono, A. N. (2018). Factors Affecting Corruption in Indonesia: Study on Local Government in Indonesia. Indonesian Journal of Sustainability Accounting and Management, 2(2), 79-89.

DOI: $10.28992 / i j s a m . v 2 i 2.41$

\section{Introduction}

Corruption is a problem that can enter into a system, institution or a country and have an impacts on creating an ineffective government system (Langseth, 1999; Lintjer, 2000; Rose-Ackerman, 1999; Jain, 2001; Schneider, 2007; World Bank, 2005; Lange, 2008; Kaptein, 2011; dela Rama, 2012). Corruption can occur in both public and private sectors, but the concern of this study is focused on the corruption in the public sector, especially the 
corrupt behavior of public officials (Caiden, 2000; Heidenheimer \& Johnston, 2002). However, acts of corruption are not only committed by the government elite but it also includes almost all the elements of state organizers (Caesar et al., 2016). The results of Indonesia Corruption Watch (ICW) survey revealed that throughout 2014 corruption cases were dominated by corruption cases in the regions further, the most subjected corrupt is local government officials (Caesar et al., 2016).

Corruption problem can occur due to poor corporate governances which performed by the government state apparatus (Black et al., 2000; Monteduro et al., 2016). According to Jensen \& Meckling (1976), corporate governance encompasses overall mechanisms and controls to ensure that the leadership acts are in accordance with the interests of the stakeholders, whereas according to Caesar et al. (2016) a conduct of poor local governance has an impact on corruption and poverty. According to Dami (2016), an example of poor local governance occurs in Banten province, this is reflected in the opinion of the Financial Audit Board (BPK) towards the Provincial Government's Financial Report (LKPD) for two consecutive years got predicated as the disclaimer.

Implementing corporate governance practices in the government requires the government to follow certain principles - such as transparency, accountability, and fairness. The application of these principles can not be separated from issues of accountability and transparency in the management of state and local finances (The Committee on the Financial Aspects of Corporate Governance, 1992). According to Said et al. (2016) corporate governance in the public sector can support effective accountability of its performance, in addition, a conduct of good integrity in the government sector able to improve the perceived government's accountability in the public. The issues of transparency and accountability issues are inseparable from the increasing abuse of authority and misconduct committed by government officials. Transparency and accountability also require the media to be faster and better in communicating to the public (Bertot et al., 2012).

Other than the corporate governance practices, government corruption can also be caused by the information system used. The act that is taken by Indonesia's Government efforts to tackle corruption is to increase transparency and accountability in the management of state financing with the provision of Regional Financial Information Systems (SIKD) as a tool to help the preparation of information for the regional budgeting and budgeting process (APBD). However, the application of information systems couldn't be depended alone, there are factors that can affect the success or failure of the system implementation. According to DeLone \& McLean (1992); Seddon (1997); Rai et al. (2002); (livari, 2005) the success of information systems is influenced by the quality of information systems generated from the associated system.

The purpose of this study is to examine the influence of corporate governance and SIKD on the corruption of local governments in Indonesia. This research is expected to contribute on the role of Parliament (DPDR) and SIKD into action to prevent corruption, especially corruption in local government.

Agency theory is a theory that focuses on the problem of information asymmetry in which agents have more information about actual performance, motivation, and goals that can potentially lead to moral hazard and one of the forms is an act of corruption. Lane (2005) argues that agency theory can be applied in public organizations, while Bergman \& Lane (1990) argue that principal relationships with agents are a very important approach for analyzing public policy commitments. The making and implementation of public policy dealing with issues of the relationship between agents and principals, namely asymmetric information, moral hazard, and adverse selection.

The agency relationships in the government sector according to Abdullah \& Halim (2006), are illustrated by the relationship between the legislature and the executive. The executive is the agent and the legislature is the principal (Moe, 1984; Halim \& Kusufi, 2012; Fozzard, 2001). The agency relationship between the executive and the legislature is also raised by Andvig et al. (2001); Lupia \& Mccubbins (2000). In this connection, the 
legislature delegates the authority to run the government to the executive. However, agency problems always occurred between principals and agents, thus, the issues that often arise between the executive and legislative is also the agency problem. According to Colombatto (2001) discretionary power on one side will lead to violations of agency contracts such as corruption in government.

Good corporate governance has long been the nightmare of many people in Indonesia. Corporate governance is required both in the corporate sector or in the public sector (Widyaningsih et al., 2017; Suteja et al., 2017; Honggowati et al., 2017). Although their understanding of good corporate governance was varied, at least most of them had imagined that with good corporate governance they will be able to have a better quality of governance. Many of them imagine that by having better corporate governance practices, the quality of public services will be better, the corruption rate will get lower, and the government is will be more concerned with the interests of society. Good governance practices can improve the climate of transparency, participation, and accountability in accordance with the basic principles of corporate governance in the public sector.

Corruption is a complex problem and a phenomenon that had been analyzed by many researchers. In this context, corruption can be analyzed from a private sector perspective (Argandoña, 2003; Lange, 2008), from a public sector perspective (Anechiarico \& Jacobs, 1994; Auriol, 2006; Auriol \& Blanc, 2009), or perceptions of corruption in a country (dela Rama, 2012; Kaptein, 2011). According to Caiden (2000); Heidenheimer \& Johnston (2002), although a problem that can occur both in the public and private sectors, but researchers focus more on the corruption in the public sector, especially research related to the corrupt behavior of public officials. According to Komisi Pemberantasan Korupsi (2006), conventional corruption eradication is not effective in reducing or eliminating long-term corruption. Further, Komisi Pemberantasan Korupsi (2006) stated that efforts should be emphasizing on comprehensive prevention activities so the efforts of action that might directly or indirectly lead to corruption will not happen. One of corruption prevention efforts according to Komisi Pemberantasan Korupsi (2006) is the implementation of corporate governance in the government sector both in the central and the local government.

According to Black et al. (2000), the linkage between corporate governance and corruption is highly relevant in the context of developing countries. For example, many developing countries have embarked on various forms of privatization-oriented reforms of state-owned enterprises which are often at the core of reform, but in some developing countries, corporate governance is still considered to be weak because it can facilitate its official to corrupt. The same opinion is also expressed by Monteduro et al. (2016) that the problem of corruption is a serious issue that attracts a lot of public attention and corruption has a strong correlation with issues of good governance, while Said et al. (2016) said good governance has a significant positive relationship with integrity practices in the public sector in Malaysia. In this case, the occurrence of corruption can be prevented by increasing the integrity of public officials. Strengthening the integrity of public officials as an effective way to build attitudes and awareness in government thus it canreduces corruption.

According to Klitgaard (1998); Gonzales de Asis (2000), the strategy to eradicate corruption is by increasing accountability. Desta (2006) states that accountability is a way to prevent corruption. In Indonesia, regional autonomy regulations require a good supervision to avoid corruption. In Indonesian government regulation No.56/2005, the regional financial information system (SIKD) is one of the government's effort to make local government financial reporting become more transparent and accountable. With regard to the application of information systems, the researcher had tested the implementation of the system, it includes the research by DeLone \& McLean (1992); Seddon (1997); Rai et al. (2002). The information system will help to improve organizational performance if the organization uses the actual information system in an efficient step (Kang, 1998), besides the problem of control in the organization also must be considered (Suprianto et al., 2017), especially related to the implementation of information systems. 
In the regulation of finance minister No. 46/2006, local governments must submit their data or information related to regional finance to the government. The implementation of SIKD which developed in local government that based upon information technology is expected to increase the accountability within the enforcement of clean government that's free from corrupt acts.

Zhu \& Kraemer (2002) stated that information systems have an impact on the increase of information value for developing countries, meaning that information systems provide good benefits (Jones et al., 2017), for example, to increase the accountability of government. Meanwhile, Haque (2000) explains the problem of accountability is it always associated with the increasing responsibility that must be implemented by the government, namely by encouraging the creation of a climate that can realize accountability. Improving and constructing government performance accountability is expected to have implications to reduce corruption issues within the government.

\section{Methods}

Population in this research is the local government in Indonesia. The sample of this study includes the local government that had reported their Local Government Financial Report (LKPD) in the period of 2010-2014 and has been audited by the Financial Audit Board (BPK). The sampling technique used purposive sampling method. Sample criteria used in this study are first, local governments that have issued its LKPD and have been audited by BPK from 2010-2014 and have data summary of BPK audit results. Secondly, the sample has complete data (examination results of the government's internal control system (SPIP)), state losses and financial reports. Third, the composition of the DPRD as a supporting party of the government and parties outside the government's coalition.

In this study, local government corruption is the amount of financial loss of the state from the findings of BPK audit within the period of 2010-2014. According to Indonesia's regulation No. 1/2004, the state/regional financial loss is a lack of money, securities, and goods, which is real and inevitable in number as a result of unlawful acts either intentionally or haphazardly. According to the regulation No. 15/2006, the institution which determines whether or not there is a state financial loss is the BPK. State financial loss data obtained through the obtained overview of examination results by BPK in the period of 2010-2014.

The corporate governance (CG) variable in this study is proxied by a comparison of the number of members of the local parliament (DPRD) as a party that supporting the government and the number of members of the regional legislative council (DPRD). Based on the agency theory, to minimize the problems arising from the asymmetry of information in the local government, the Regional House of Representatives (DPRD) in accordance with regulation No. 17/2014 has the duty and authority to effectively supervise the implementation of regional regulations and local government budgets. The score used to measure corporate governance variable is between 0 to 1 . Regional financial information systems are implemented to improving the performance of the local government. According to Sharda et al. (1988); Davis (1989) information technology systems are the main factors that are affecting performance. SIKD variable in this study used variable dummy measurement with scale measurement of 1 for SIKD developed by BPKP and o for SIKD developed with non-BPKP.

Control variables weaknesses of accounting and reporting controls in this study are measured by the amount of BPK audit findings in the number of cases for weaknesses in accounting and reporting controls. The amount findings of cases of weakness is sourced from the summary of BPK audit results for the period of 2010 to 2014. The control variables of control weaknesses of controlling the execution of budgeted income and expenditure in this study are measured by the amount of BPK audit findings in the number of cases for the weaknesses of controlling the execution of budgeted income and expenditure. The findings amount of cases 
of weakness is sourced from the summary of BPK audit results for the period of 2010 to 2014. The control variables of the Weakness of the Internal Control Structure in this study were measured by the amount of BPK audit findings in the number of cases for the Weakness of the Internal Control Structure. The amount finding of cases of weakness is sourced from the summary of BPK audit results for the period 2010 to 2014. The control variables of local government size in this study are measured by the total assets owned by regional governments from 2010 to 2014. The total assets are derived from the total amount of current assets, fixed assets and other assets owned by local governments. Information on assets owned by the local government is known from the balance sheet which presented in LKPD. The control variables of local government assets in this study are measured by the amount of Local Revenue (PAD) of each regional government in the period 2010 to 2014. According to Christensen \& Lægreid (2002), high performance in a government is a signal of good public management. PAD is one of the things that shows the performance of the region to generate income independently. The control variables of balancing funds in this study are measured by the number of total balancing funds listed in the balance sheet report from 2010 to 2014. According to Robbins \& Austin (1986), intergovernmental revenue reflects the dependence level of local governments towards central and other governments.

Test the hypothesis in this study uses regression analysis, while the model research used:

$C O R=a+b 1 C G+b 2 S I K D+b 3 S P I P \_K P A P+b 4 S P I P \_K P P A P B+b 5 S P I P \_S P I+b 6 S P+b 7 K P D+b 8 D P$

Where:

COR $=$ Local government corruption

CG $=$ Corporate governance

SIKD $\quad=$ Regional financial information system

SPIP-KPAP = Weaknesses of accounting and reporting controls

SPIP-KPPAPB = Weaknesses of controlling the execution of the budgeted income and expenditure

SPIP-SPI = Weakness of the internal control structure

$\mathrm{SP} \quad=$ Size of local government

KPD $\quad=$ Asset of local government

DP $\quad=$ Balance fund

\section{Results and Discussion}

Based on data obtained, the number of regencies/municipalities in Indonesia reach as many as 514. This study used the data consist of local government regencies/municipalities that have completed data which in accordance with the data required in this study. After reviewing the LKPD - which has been audited by BPK, on the period of 2010-2014, Regarding the result of BPK audit and data composition of the number of DPRD from each regency/municipalities, there are some data that cannot be analyzed.

In the Table 1 it is explained that the amount of data that meets the completeness requirements for analysis is 380 . After analysis, from 380 data there are some outlier data, therefore the outlier data is not used in the next analysis. The amount of outlier data that can not be used for further analysis is 155 , so the data performed for the analysis is 225 with a 5 year period (2010-2014) so that the observed number is 1.125 . The results of descriptive statistical analysis of the variables used in this study either dependent variables, independent variables, and control variables in detail are presented in the Table 2. 
Table 1 Procedure in Sampling

\begin{tabular}{lc}
\hline \multicolumn{1}{c}{ Information } & Number of Local Government \\
\hline Local Government (regencies/municipalities) & 514 \\
Data of LKPD and IHPS not resented in sequence (2010-2014) & 81 \\
Has no DPRD composition & 53 \\
Local Government (regencies/municipalities) selected & 380 \\
\hline
\end{tabular}

Table 2 describes the maximum value of local government corruption from 225 regencies/municipalities in Indonesia is Rp10,929.34 million while the lowest value of corruption is Rpo.00. The highest score of corporate governance score is 1 and the lowest is 0.02. The average corporate governance score is 0.6. (higher composition of independent DPRD). The SIKD scores in maximum 1 and minimum 0 , meaning that local governments will use SIKD derived from the Regional Audit Board (BPKP) and non-BPKP (SIKD program created for non-BPKP program developers).

Table 2 Descriptive Analysis Result

\begin{tabular}{|c|c|c|c|c|}
\hline Variable & Max & Min & Average & SD \\
\hline COR & $10,929 \cdot 34$ & 0 & 205.60 & 617.501 \\
\hline$C G$ & 1 & 0.02 & 0.6 & 0.227 \\
\hline SIKD & 1 & 0 & 0.72 & 0.87 \\
\hline SPIP_KPAP & 14 & 0 & 3 & 3.89 \\
\hline SPIP_KPPAPB & 43 & 0 & 2.2 & 2.92 \\
\hline SPIP_SPI & 11 & 0 & 1.78 & 1.77 \\
\hline SP & $3,860,593.8$ & 130,982 & $2,830,283$ & $3,452,664$ \\
\hline KPD & $11,251,724$ & 102 & $191,137 \cdot 3$ & $540,402.3$ \\
\hline DP & $2,498,371$ & 0 & $741,419.4$ & $347,958.2$ \\
\hline
\end{tabular}

Notes: $\mathrm{COR}$ = Local Government Corruption; CG = Corporate governance; SIKD = Regional Financial Information System; SPIP_KPAP = Weaknesses of Accounting and Reporting Controls; SPIP_KPPAPB = Weaknesses of Controlling the Execution of the Budgeted Income and Expenditure; SPIP_SPI = Weakness of the Internal Control Structure; SP= Size of Local Government; KPD = Asset of Local Government; DP = Balance Fund.

Descriptive analysis results for control variables weaknesses of accounting and reporting controls found the high cases reach 14 cases, the lowest is 0 and the average is 3 cases. Control variable weaknesses of controlling the execution of the budgeted income and expenditure found the highest case of 43 cases, the lowest 0 and the average is 2.2 cases. Control variables weakness of the Internal control structure found the highest case of 11 cases, the lowest 0 and the average 1.78 cases. Size of Local government control variables which proxied by assets owned by local governments, the highest value is $\mathrm{Rp} 3,860,593.8$ million, the lowest value is Rp130,982 million and on average Rp2,830,283 million. The asset of Local government control variable which proxied by Local Revenue (PAD) found the highest value as much as 11,251,724 million, the lowest value 
reach Rp102 million and the average is 191,137.3 million. While the control variable of balancing fund the highest value was 2,498,371 million, the lowest value is 0 and the average are 741,419.4 million.

Table 3 Regression Analysis

\begin{tabular}{|c|c|c|c|}
\hline Variable & Coefficient & t-stat & Prob. \\
\hline Constant & 302.4554 & 4.303063 & 0 \\
\hline CG & -233.1406 & -2.732027 & $0.0064 * * *$ \\
\hline SIKD & -39.7843 & -1.026755 & 0.3048 \\
\hline SPIP_KPAP & -0.7572 & -0.160106 & 0.8728 \\
\hline SPIP_KPPAPB & -11.3754 & -1.752886 & $0.0799^{*}$ \\
\hline SPIP_SPI & -4.0916 & -0.378815 & 0.7049 \\
\hline SP & $1.75 \mathrm{E}-06$ & 0.260519 & 0.7945 \\
\hline KPD & $6.54 \mathrm{E}-05$ & 1.689702 & $0.0914^{*}$ \\
\hline DP & 0.000123 & 1.921281 & $0.0550^{*}$ \\
\hline $\mathrm{R}^{2}$ & 0.0181 & & \\
\hline Adj. $R^{2}$ & 0.0110 & & \\
\hline F-stat & 2.5654 & & \\
\hline Prob. & $0.0089 * * *$ & & \\
\hline
\end{tabular}

Test results in Table 3 adjusted $\mathrm{R}^{2}$ value of 0.011 indicate that local government corruption can be explained by corporate governance and SIKD variables as $1.3 \%$. Meanwhile, the CG variable has a t-value -2.7320 with a probability value of 0.0064 that is smaller than $1 \%$. The negative CG regression coefficient indicates that the higher the composition of DPRD independency then the local government corruption will decrease ( $\mathrm{H}_{1}$ accepted), while the SIKD variable has t-value equal to -1.02675 with a probability value of 0.3048 . These results indicate that the SIKD variable does not reduce the level of corruption of local governments in Indonesia ( $\mathrm{H}_{2}$ is rejected).

The test results show that corporate governance which proxied by the function of supervision by independent parliamentary has an effect on the corruption of local governments in Indonesia. In Mardiasmo (2009) the strengthening of supervisory function can be done through optimizing the function and role of DPRD as a balance of power for local executives. The composition of the DPRD as a watchdog for a more independent government (beyond the party supporting the government) can reduce the occurrence of conflicts of interest when individuals or groups engage in various interests.

The results of this hypothesis testing support the previous research that examines the influence of corporate governance on corruption. According to Black et al. (2000), the linkage between corporate governance and corruption is highly relevant in the context of developing countries. Some developing countries generally have weak corporate governance conditions so that their officials can easily conduct corrupt acts. The challenge is very heavy, given the behavior of public services conducted by the government over a certain period of time has been indicated various forms of actions, activities, and modes to conduct on 
the practice of corruption, collusion, and nepotism, thus, Indonesia is considered to be one country that has a high index of corruption (Transparency International, 2017).

The same opinion also expressed by Monteduro et al. (2016) who said that the problem of corruption is an issue that has a close correlation with good governance. Corruption can be prevented by increasing the integrity of public officials. Strengthening the integrity of public officials in the sector is one of the effective ways to build attitudes and awareness in government and the public as a whole in combating or at least reducing corruption effectively.

According to the view of the Dami (2016), one of the efforts to prevent corruption is the implementation of corporate governance in the government sector, both central and local government. The results of this study also support the results of research conducted by (Said et al., 2016) who said that good corporate governance has a significant positive relationship with the practice of integrity in the public sector. The occurrence of corruption can be prevented by the increasing integrity of public officials, meaning that the implementation of good corporate governance practices in the government sector can prevent the act of corruption by local officials.

The test results also show that SIKD has no effect on the corruption of local government in Indonesia, this result was different with the result of some previous research. Zhu \& Kraemer (2002) states that information systems have an impact on the value of information, meaning that information systems can improve accountability in the government. Meanwhile, according to Klitgaard (1998); Gonzales de Asis (2000), the strategy to eradicate corruption is by increasing accountability, this opinion is similar to Desta (2006) view that accountability is a way to prevent corruption.

The same view is also explained by Haque (2000) which says accountability can be linked to increased governmental responsibility. Good government performance accountability implies a reduced corruption in government. In Indonesia, problems related to information systems are described in the minister of finance regulation No. 46/2006, that local governments are obliged to convey information about the regional finances to the central government. The adoption of information technology-based SIKD is expected to increase accountability in the conduct of clean and corruption-free government.

\section{Conclusion}

This study concludes that corporate governance negatively affects the corruption of local government in Indonesia, the higher the corporate governance the corruption of local government in Indonesia will tend to decrease. In this case, corporate governance is proxied by comparison of the number of independent DPRDs with total DPRD in a local government. The results of this study indicate that the magnitude of the number of independent DPRDs composition (DPRDs that do not support and coalesce with the government) can be a function of maximum supervision in the regime of the ruling government within a region.

Meanwhile, the results of this study also concluded that SIKD has no effect on corruption that occurred in local government in Indonesia. This result is not in line with the government's expectation as regulated in Minister of Finance Regulation No.46/2006 The implementation of SIKD that's developed in the local government and based on information technology is expected to increase the accountability in the conduct of governance that's clean and free from corruption, but the results of this study indicate that SIKD has not been able to reduce or prevent corruption in local government in Indonesia.

The conduct of corruption in Indonesia local government needs supervision and continuity efforts. To achieve these objectives, the implementation of good corporate governance in every regencies/municipalities government in Indonesia must be realized as a means to prevent corruption in local government in Indonesia. 
In addition, it is necessary to examine the SIKD which is a government program in order to realize transparency in the government financial sector, especially the regencies/municipalities government.

The data in this study used a sample as 514 regencies/municipalities of Indonesia Local Governments in, but the sample that can be used only reach 225 regencies/municipalities. Moreover, with limited data, local government corruption predictors observed only use two variables, thus, other predictors are still possible to be investigated. Limitations of the methodology in this study are the value of adjusted $R^{2}$ is still considered to be small. Hence, further research is advised to examine other variables that can affect the corruption of local governments.

The eradication of corruption must be conducted continuously, and the support of all elements of society will accelerate efforts to create a clean and authoritative government. For further research, it is expected to consider other variables such as the impact of local government corruption and the efforts to eradicate corruption of local governments. In addition, this research can be developed in various correlational research models that might affect the local government corruption.

\section{References}

Abdullah, S., \& Halim, A. (2006). Studi atas Belanja Modal pada Anggaran Pemerintah Daerah dalam Hubungannya dengan Belanja Pemeliharaan dan Sumber Pendapatan. Jurnal Akuntansi Pemerintah, 2(2), $17-32$.

Andvig, J. C., Fjeldstad, O.-H., Amundsen, I., Sissener, T., \& Søreide, T. (2001). Corruption: A Review of Contemporary Research. Bergen: Chr. Michelsen Institute.

Anechiarico, F., \& Jacobs, J. B. (1994). Visions of Corruption Control and the Evolution of American Public Administration. Public Administration Review, 54(5), 465-473.

Argandoña, A. (2003). Private-to-private Corruption. Journal of Business Ethics, 47(3), $253-267$. https://doi.org/10.1023/A:1026266219609

Auriol, E. (2006). Corruption in Procurement and Public Purchase. International Journal of Industrial Organization, 24(5), 867-885. https://doi.org/10.1016/j.jindorg.2005.11.001

Auriol, E., \& Blanc, A. (2009). Capture and Corruption in Public Utilities: The Cases of Water and Electricity in Sub-Saharan Africa. Utilities Policy, 17(2), 203-216. https://doi.org/10.1016/j.jup.2008.07.005

Bergman, M., \& Lane, J.-E. (1990). Public Policy in a Principal-Agent Framework. Journal of Theoretical Politics, 2(3), 339-352. https://doi.org/10.1177/0951692890002003005

Bertot, J. C., Jaeger, P. T., \& Grimes, J. M. (2012). Promoting Transparency and Accountability Through ICTs, Social Media, and Collaborative E-Government. Transforming Government: People, Process and Policy, 6(1), 78-91. https://doi.org/10.1108/17506161211214831

Black, B., Kraakman, R., \& Tarassova, A. (2000). Russian Privatization and Corporate Governance: What Went Wrong? Stanford Law Review, 52(6), 1731-1808.

Caesar, A., Easter, L., \& Yuntho, E. (2016). Catatan Pemantauan Perkara Korupsi yang Divonis oleh Pengadilan Selama Januari - Juni 2016. Retrieved from https://www.antikorupsi.org/sites/default/files/files/Siaran Pers/TREN VONIS 1-2016 Final HMP.pdf

Caiden, G. E. (2000). Dealing with Administrative Corruption. In T. Cooper (Ed.), Handbook of Administrative Ethics (2nd ed.). New York: Routledge.

Christensen, T., \& Lægreid, P. (2002). New Public Management: The Transformation of Ideas and Practice. Aldershot: Ashgate Publishing.

Colombatto, E. (2001). Discretionary Power, Rent-Seeking and Corruption (ICER Working Paper).

Dami, L. (2016, April 13). KPK Nilai Tata Kelola Pemprov Banten Masih Buruk. Http://Www.Beritasatu.Com/. Retrieved from http://www.beritasatu.com/hukum/359770-kpk-nilai-tata-kelola-pemprov-banten-masihburuk.html

Davis, F. D. (1989). Perceived Usefulness, Perceived Ease of Use, and User Acceptance of Information Technology. MIS Quarterly, 13(3), 319-340. 
dela Rama, M. (2012). Corporate Governance and Corruption: Ethical Dilemmas of Asian Business Groups. Journal of Business Ethics, 109(4), 501-519. https://doi.org/10.1007/s10551-011-1142-0

DeLone, W. H., \& McLean, E. R. (1992). Information Systems Success: The Quest for the Dependent Variable. Information Systems Research, 3(1), 60-95. https://doi.org/10.1287/isre.3.1.60

Desta, Y. (2006). Designing Anti-Corruption Strategies for Developing Countries: A Country Study of Eritrea. Journal of Developing Societies, 22(4), 421-449. https://doi.org/10.1177/0169796X06072568

Fozzard, A. (2001). The Basic Budgeting Problem: Approaches to Resource Allocation in the Public Sector and their Implications for Pro-Poor Budgeting (No. 147).

Gonzales de Asis, M. (2000). Reducing Corruption at the Local Level (World Bank Institute).

Halim, A., \& Kusufi, M. S. (2012). Akuntansi Sektor Publik: Akuntansi Keuangan Daerah (4th ed.). Jakarta: Salemba Empat.

Haque, M. S. (2000). Significance of Accountability under the New Approach to Public Governance. International Review of Administrative Sciences, 66(4), 599-617. https://doi.org/10.1177/0020852300664004

Heidenheimer, A. J., \& Johnston, M. (2002). Political Corruption: Concepts and Contexts. New Brunswick: Transaction Publishers.

Honggowati, S., Rahmawati, R., Aryani, Y. A., \& Probohudono, A. N. (2017). Corporate Governance and Strategic Management Accounting Disclosure. Indonesian Journal of Sustainability Accounting and Management, 1(1), 23-30. https://doi.org/10.28992/ijsam.v1i1.24

livari, J. (2005). An Empirical Test of the DeLone-McLean Model of Information System Success. ACM SIGMIS Database: The DATABASE for Advances in Information Systems, 36(2), 8-27.

Jain, A. K. (2001). Corruption: A Review. Journal of Economic Surveys, 15(1), 71-121. https://doi.org/10.1111/14676419.00133

Jensen, M. C., \& Meckling, W. H. (1976). Theory of the Firm: Managerial Behavior, Agency Costs and Ownership Structure. Journal of Financial Economics, 3(4), 305-360. https://doi.org/10.1016/0304-405X(76)90026-X

Jones, P., Wynn, M., Hillier, D., \& Comfort, D. (2017). The Sustainable Development Goals and Information and Communication Technologies. Indonesian Journal of Sustainability Accounting and Management, 1(1), 115. https://doi.org/10.28992/ijsam.v111.22

Kang, S. (1998). Information Technology Acceptance: Evolving with the Changes in the Network Environment. In Proceedings of the Thirty-First Hawaii International Conference on System Sciences (Vol. 1, pp. 413-423). Kohala Coast: IEEE. https://doi.org/10.1109/HICSS.1998.653126

Kaptein, M. (2011). From Inaction to External Whistleblowing: The Influence of the Ethical Culture of Organizations on Employee Responses to Observed Wrongdoing. Journal of Business Ethics, 98(3), 513530. https://doi.org/10.1007/s10551-010-0591-1

Klitgaard, R. (1998). International Cooperation Against Corruption. Finance and Development, 3-6.

Komisi Pemberantasan Korupsi. (2006). Pelaksanaan Tata Kelola Pemerintahan yang Baik. Jakarta: Komisi Pemberantasan Korupsi.

Lane, J.-E. (2005). Public Administration and Public Management: The Principal-Agent Perspective (1st ed.). London: Routledge.

Lange, D. (2008). A Multidimensional Conceptualization of Organizational Corruption Control. Academy of Management Review, 33(3), 710-729. https://doi.org/10.5465/amr.2008.32465742

Langseth, P. (1999). Prevention: An Effective Tool to Reduce Corruption. In ISPAC conference on Responding to the Challenge of Corruption. Vienna.

Lintjer, J. (2000). The Fight against Corruption: How a Regional Development Bank Can Help. In 2nd Regional Anti-Corruption Conference.

Lupia, A., \& Mccubbins, M. D. (2000). Representation or Abdication? How Citizens Use Institutions to Help Delegation Succeed. European Journal of Political Research, 37(3), 291-307. https://doi.org/10.1023/A:1007068904236

Mardiasmo, M. (2009). Akuntansi Sektor Publik (4th ed.). Yogyakarta: Andi Publisher.

Moe, T. M. (1984). The New Economics of Organization. American Journal of Political Science, 28(4), 739-777. 
Monteduro, F., Hinna, A., \& Moi, S. (2016). Governance and Corruption in the Public Sector: An Extended Literature Review. In A. Hinna, L. Gnan, \& F. Monteduro (Eds.), Governance and Performance in Public and Non-Profit Organizations (Studies in Public and Non-Profit Governance) (pp. 31-51). Emerald Group Publishing Limited. https://doi.org/10.1108/S2051-663020160000005002

Rai, A., Lang, S. S., \& Welker, R. B. (2002). Assessing the Validity of IS Success Models: An Empirical Test and Theoretical Analysis. Information Systems Research, 13(1), 50-69. https://doi.org/10.1287/isre.13.1.50.96

Robbins, W. A., \& Austin, K. R. (1986). Disclosure Quality in Governmental Financial Reports: An Assessment of the Appropriateness of a Compound Measure. Journal of Accounting Research, 24(2), 412-421.

Rose-Ackerman, S. (1999). Corruption and Government: Causes, Consequences, and Reform. Cambridge: Cambridge University Press. https://doi.org/10.1017/CBO9781139175098

Said, J., Alam, M. M., \& Khalid, M. A. (2016). Relationship between Good Governance and Integrity System: Empirical Study on the Public Sector of Malaysia. Humanomics, 32(2), 151-171. https://doi.org/10.1108/H-022016-0008

Schneider, F. (2007). Shadow Economies and Corruption All Over the World: New Estimates for 145 Countries. Economics: The Open-Access, Open-Assessment E-Journal, 1(2007-9).

Seddon, P. B. (1997). A Respecification and Extension of the DeLone and McLean Model of IS Success. Information Systems Research, 8(3), 240-253.

Sharda, R., Barr, S. H., \& McDonnell, J. C. (1988). Decision Support System Effectiveness: A Review and an Empirical Test. Management Science, 34(2), 139-159.

Suprianto, E., Suwarno, S., Murtini, H., Rahmawati, R., \& Sawitri, D. (2017). Audit Committee Accounting Expert and Earnings Management with "Status" Audit Committee as Moderating Variable. Indonesian Journal of Sustainability Accounting and Management, 1(2), 49-58. https://doi.org/10.28992/ijsam.v1i2.16

Suteja, J., Gunardi, A., \& Auristi, R. J. (2017). Does Corporate Social Responsibility Shape the Relationship between Corporate Governance and Financial Performance? Indonesian Journal of Sustainability Accounting and Management, 1(2), 59-68. https://doi.org/10.28992/ijsam.v1i1.33

The Committee on the Financial Aspects of Corporate Governance. (1992). The Financial Aspects of Corporate Governance. London: The Committee on the Financial Aspects of Corporate Governance and Gee and Co. Ltd.

Transparency International. (2017). Corruption Perceptions Index 2016. Retrieved from https://www.transparency.org/news/feature/corruption_perceptions_index_2016

Widyaningsih, I. U., Gunardi, A., Rossi, M., \& Rahmawati, R. (2017). Expropriation by the Controlling Shareholders on Firm Value in the Context of Indonesia: Corporate Governance as Moderating Variable. International Journal of Managerial and Financial Accounting, 9(4), 322-337. https://doi.org/10.1504/IJMFA.2017.10009973

World Bank. (2005). The World Bank Research Program 2004: Abstracts of Current Studies. The World Bank. https://doi.org/10.1596/978-0-8213-6457-4

Zhu, K., \& Kraemer, K. L. (2002). e-Commerce Metrics for Net-Enhanced Organizations: Assessing the Value of e-Commerce to Firm Performance in the Manufacturing Sector. Information Systems Research, 13(3), 275295. https://doi.org/10.1287/isre.13.3.275.82 